\title{
AGRICULTURAL WASTES AS ALTERNATIVE SUBSTRATES IN THE PRODUCTION OF CONILON COFFEE SEEDLINGS
}

\author{
RESÍDUOS AGRÍCOLAS COMO SUBSTRATOS ALTERNATIVOS NA PRODUÇÃO \\ DE MUDAS DE CAFÉ CONILON
}

\section{Louise Pinto GUISOLFI'; Paola Alfonsa Vieira LO MONACO²; Marcelo Rodrigo KRAUSE ${ }^{3}$; Caroline Merlo MENEGHELLI ${ }^{3}$; Karoline Matiello ALMEIDA ${ }^{1}$; Lorena Aparecida Merlo MENEGHELLI ${ }^{1}$; Gustavo Haddad Souza VIEIRA ${ }^{2}$}

1. Estudante de mestrado, Universidade Federal de Viçosa, UFV, Campos de Viçosa, MG, Brasil. louisepguisolfi@gmail.com; 2. Docente, Instituto Federal do Espírito Santo, Ifes, campus Santa Teresa, ES, Brasil; 3. Estudante de doutorado, Universidade Federal de Viçosa, UFV, Campos de Viçosa, MG, Brasil

\begin{abstract}
Research related to the use of agricultural residues as alternatives to commercial substrates has become fundamental for reducing the production costs of coffee seedlings. The objective of this study was to evaluate the effect of residues of pepper (Piper nigrum) powder, coffee (Coffea) husk, coconut (Cocos nucifera) fiber and pine (Pinus) bark as alternative substrates in the development of coffee (Coffea canephora) seedlings in tubes. The experiment was carried out at the Demuner Seedling Nursery, in the municipality of São Roque do Canaã, Espírito Santo, Brazil. The experimental design was completely randomized, with six treatments: T0- Bioplant ${ }^{\circledR}$ commercial substrate (control); and from T1 to T5, increasing proportions (\%) of pepper powder and decreasing coconut fiber and pine bark $(0 / 20 / 50,10 / 15 / 45,20 / 10 / 40$, $30 / 5 / 35$ and 40/0/30) and fixed proportions of coffee husk (30\%). At 120 days after staking, we evaluated the plant height, number of leaves, stem diameter, shoot dry mass and root dry mass. Any of the substrates containing different proportions of agricultural residues can be used as an alternative to the commercial substrate in the production of Conilon coffee seedlings since most of the growth variables evaluated did not differ from the control. Due to the high availability of pepper powder in the region, we recommended the substrate with $40 \%$ pepper powder, $30 \%$ coffee husk and $30 \%$ pine bark.
\end{abstract}

KEYWORDS: Coffea canephora. Agricultural residues. Growing.

\section{INTRODUCTION}

The initial development of perennial crops, such as coffee (Coffea canephora), is influenced by several climatic and nutritional factors, as well as those related to the quality of the seedlings used (VALLONE et al., 2010a). The quality of the seedlings has a direct influence on the success of coffee crop formation, which must have vigorous development and a well-formed root system (MARTINS et al., 2015). Therefore, all precautions should be taken to ensure the conditions favor the roots development and the balance between the root system and the aboveground part (OLIVEIRA; OLIVEIRA; MOURA, 2012).

The two main production systems currently used for coffee seedlings are the plastic bag (conventional) and the tubes. In the conventional system, the seedlings are produced in polyethylene plastic bags, with the substrate composed of soil and cattle manure and enriched with chemical fertilizers. In the case of seedlings produced in polyethylene tubes, commercial substrates have been commonly used.
The production of coffee seedlings in tubes has advantages such as lower chance of contamination; direct growth and reduce problems with root folding (bent top); stimulate lateral root growth; take up less space in the nursery; reduce the incidence of weeds; reduce transport costs: and use less substrate volume (TOMAZ et al., 2015). Thus, it is of great importance that the substrate composition contains all the nutrients necessary for the plants development and that they are available, besides presenting aspects such as large porosity, high cation exchange capacity, good water retention, free of pests, pathogens and be economically viable (SAN-TANA DE ALMEIDA et al., 2011).

In the search for sustainable alternatives, and mainly to reduce costs in the acquisition of commercial substrates, several studies have been carried out, aiming at the use of residues generated in agricultural activities as components of substrates for the production of coffee seedlings (VALLONE et al., 2010b; ALMEIDA et al., 2011; MENEGHELLI et al., 2018).

Among some residues generated in large quantities in the state of Espírito Santo, Brazil, and 
with potential to be used in the composition of alternative substrates for the production of Conilon coffee seedlings in tubes, pine bark, coconut fiber and coffee husk stand out.

Several attributes make these residues interesting in the composition of an alternative substrate to the commercial one. Examples of these attributes are the ease of drainage of the pine bark (MARTIN et al., 2006), the high porosity and presence of micropores responsible for good aeration and retention of water in the coconut fiber environment (ZORZETO et al., 2014), and the presence of nutrients in the coffee husk, especially nitrogen and potassium (ASSIS et al., 2011).

Another residue generated in high quantity in ES, Brazil, is the one that comes from the black pepper processing, popularly known as "pepper powder". The PP is composed of plant remains, such as leaves, branches, inflorescence remnants and poorly-formed grains of the pepper plant, which during the drying step, are burned and released from the dryer.

In view of the above, we consider that the use of alternative substrates made with agricultural residues can be a viable and sustainable alternative for the production of Coffea canephora Conilon coffee seedlings in tubes since it aims at the elimination of an environmental problem, due to the inadequate disposal, and, simultaneously, promotes the reduction in coffee production costs.

This study aimed to evaluate the technical viability and the effect of the composition of pepper powder, coffee straw, coconut fiber and pine bark as an alternative substrate on coffee seedling growth.

\section{CONTENTS}

Table 1. Substrates formulated to produce the coffee seedlings

\begin{tabular}{ll}
\hline Treatment number & Substrate \\
\hline T0 & Bioplant ${ }^{\circledR}$ commercial substrate \\
T1 & $0 \% \mathrm{PP}+30 \% \mathrm{CH}+20 \% \mathrm{CF}+50 \% \mathrm{~PB}$ \\
T2 & $10 \% \mathrm{PP}+30 \% \mathrm{CH}+15 \% \mathrm{CF}+45 \% \mathrm{~PB}$ \\
T3 & $20 \% \mathrm{PP}+30 \% \mathrm{CH}+10 \% \mathrm{CF}+40 \% \mathrm{~PB}$ \\
T4 & $30 \% \mathrm{PP}+30 \% \mathrm{CH}+5 \% \mathrm{CF}+35 \% \mathrm{~PB}$ \\
T5 & $40 \% \mathrm{PP}+30 \% \mathrm{CH}+0 \% \mathrm{CF}+30 \% \mathrm{~PB}$ \\
\hline
\end{tabular}

PP: pepper powder. CH: coffee husk. CF: coconut fiber. PB: pine bark.

The T0 treatment was considered as the conventional treatment because the commercial substrate was regarded as the traditional one used by the Conilon coffee seedling producers in the region. The treatments $\mathrm{T} 1$ to $\mathrm{T} 5$ were idealized with increasing proportions of PP and decreasing CF and
The experiment was carried out from November 2016 to March 2017 at the seedling nursery of Demuner Viveiro Company,in the municipality of São Roque do Canaã, Espírito Santo, Brazil (latitude: 1949'S, longitude 40³8'W, and altitude of $130 \mathrm{~m}$ ).

The residues used in the composition of the alternative substrate for the production of coffee seedlings were the from the processing of pepper the pepper powder (PP) and, also, coffee husk $(\mathrm{CH})$, pine bark $(\mathrm{PB})$ and coconut fiber $(\mathrm{CF})$. The clones of the LB1 variety were planted in tubes where they contained the substrate composed of the residues together with the slow-release fertilizer (Osmocote).

The chemical and physical-chemical characterization of the residues used was carried out at the Laboratory of Water Quality and Solid Residues of the IFES, Santa Teresa Campus. The physical-chemical analysis consisted of the determination of the electrical conductivity by means of a bench conductivity meter. The chemical analysis included the measurement of the $\mathrm{pH}$ by means of a bench $\mathrm{pH}$ meter and the quantification of the concentrations of easily oxidizable organic carbon, total organic carbon, total nitrogen, phosphorus, potassium and calcium (DE MATOS, 2015).

The experimental design was completely randomized, with six treatments and six replicates. Each experimental unit contained 18 seedlings, totaling 648 seedlings.

The seedlings were placed in the nursery under a 50\% shade and were arranged in grids with vertical rows of 18 tubes. Each repetition had 10 rows of border, five rows each side. Thus, six central seedlings of the row were evaluated, totaling 216 seedlings. The compositions of the treatments are shown in (Table 1).
$\mathrm{PB}$, due to the high availability of PP in ES (Brazil) and the fact that $\mathrm{CF}$ and $\mathrm{PB}$ still constitute a cost of acquisition, albeit less than the commercial substrate, to make up the substrate. Thus, alternative materials, such as PP, have high relevance to be 
studied as an alternative to commercial substrates, or even other wastes that have costs to be acquired.

In this research, we used the clone variety LB1, being the seedlings produced from plantlets obtained from the orthotropic branch of the Conilon coffee tree and planted in plastic tubes. Irrigation was performed daily, maintaining the substrate moisture near the field capacity.

The field experiment and thus, the evaluation of the biometric and gravimetric variables, lasted approximately 120 days. Among the biometric variables, we assessed the number of leaves (NL), plant height (PH) and diameter of the stem (DS). Among the gravimetric analyzes, we evaluated the shoot dry mass (SDM) and root dry mass (RDM).

To obtain the $\mathrm{PH}$, we used a ruler, measuring it from the base of the stem to the apical bud that gave rise to the last leaf. The DS was measured by using a precision digital caliper.

To obtain the SDM and RDM, the seedlings close to the substrate were cut, carefully washing the roots in running water on a sieve. Then, the aboveground part and the roots were packed in paper bags and placed in a stove with forced air circulation at $65{ }^{\circ} \mathrm{C}$ until constant weight. Subsequently, the materials were weighed on an electronic precision scale $( \pm 0.01 \mathrm{~g})$.

The data were submitted to analysis of variance by the $\mathrm{F}$ test, and the means were compared by the Dunnett test (5\%). All the statistical analysis were carried out using the Assistat 7.7 program (SILVA; AZEVEDO, 2016).

The table below (Table 2) presents the chemical and physical-chemical attributes of $\mathrm{CF}$, $\mathrm{PP}, \mathrm{CH}$ and $\mathrm{PB}$ used in the experiment.

Table 2. Chemical and physical-chemical characteristics of coffee husk (CH) (ASSIS et al., 2011), coconut fiber $(\mathrm{CF})$, pepper powder $(\mathrm{PP})$ and pine bark $(\mathrm{PB})$.

\begin{tabular}{lllllllll}
\hline \multirow{2}{*}{ Residue } & $\mathrm{pH}^{1}$ & $\begin{array}{l}\mathrm{EC} \\
\mathrm{dS} \mathrm{m}\end{array}$ & $\mathrm{CO}_{\mathrm{fo}}$ & $\mathrm{CO}_{\mathrm{T}}$ & $\mathrm{N}_{\mathrm{T}}$ & $\mathrm{P}$ & $\mathrm{K}$ & $\mathrm{Ca}$ \\
$\mathrm{CH}$ & - & - & - & - & 1.79 & 0.13 & 1.99 & 0.44 \\
$\mathrm{CF}$ & 7.15 & 0.09 & 57.1 & 74.1 & 0.66 & 0.05 & 0.14 & - \\
$\mathrm{PP}$ & 7.5 & 1.921 & 14.0 & 18.2 & 2.09 & 0.22 & 0.33 & - \\
$\mathrm{PB}$ & 5.5 & 0.00113 & 37.0 & 48.0 & 0.40 & 0.10 & 0.17 & - \\
\hline
\end{tabular}

${ }^{1} \mathrm{pH}$ : hydrogen ionic potential in water. EC: electrical conductivity. $\mathrm{CO}_{\mathrm{fo}}$ : easily oxidizable organic carbon. $\mathrm{CO}_{\mathrm{T}}$ : total organic carbon. $\mathrm{N}_{\mathrm{T}}$ : total nitrogen. P: phosphorus. K: potassium. Ca: calcium.

The table below (Table 3) contains the averages for each of the analyzed variables, as well as the Dunnett test result, comparing the mean values of the treatments with increasing levels of PP
(T1 to T6) against the control treatment (T0) in the Conilon coffee seedlings, to 120 days after the planting of the plantlets.

Table 3. Mean values of plant height (PH), number of leaves (NL), stem diameter (DS), shoot dry mass (SDM) and root dry mass (RDM) of Conilon coffee seedlings grown on commercial (T0) and alternative (T1 to T5) substrates with increasing levels of pepper powder and decreasing levels of coconut fiber and pine bark, 120 days after planting the plantlets.

\begin{tabular}{llllllll}
\hline \multirow{2}{*}{ Variable } & \multicolumn{9}{c}{ Treatment } & \multirow{2}{*}{ Error $\alpha$} \\
\cline { 2 - 7 } & Commercial substrate $(\mathrm{T} 0)$ & $\mathrm{T} 1$ & $\mathrm{~T} 2$ & $\mathrm{~T} 3$ & $\mathrm{~T} 4$ & $\mathrm{~T} 5$ & \\
\hline PH $(\mathrm{cm})$ & 17.71 & 20.05 & $21.77 *$ & 19.40 & 20.00 & 19.24 & 0.0297 \\
NL (number) & 9.25 & 10.17 & 9.50 & 10.08 & 9.17 & 9.67 & 0.6257 \\
DS (mm) & 4.21 & 4.48 & 4.39 & 4.28 & 4.46 & 4.37 & 0.4472 \\
SDM (g) & 2.77 & 3.09 & 3.06 & 3.04 & 3.06 & 3.12 & 0.3473 \\
RDM (g) & 1.19 & 1.28 & 1.35 & 1.32 & 1.36 & 1.40 & 0.2632 \\
\hline
\end{tabular}

Averages followed by an asterisk $(*)$ in the lines differ from the control by Dunnett's test $(\mathrm{P}<0.05)$.

We observed that except for the $\mathrm{PH}$ variable, there was no difference $(\mathrm{P}>0.05)$ between the treatments for the NF, DS, SDM and RDM variables, showing that any of the alternative substrates can be used to replace the commercial substrate (Table 3). Among the alternatives, the substrate containing $40 \% \mathrm{PP}+30 \% \mathrm{CH}+30 \% \mathrm{~PB}$ may be an alternative to the substrate comprising $30 \% \mathrm{CH}+20 \% \mathrm{CF}+50 \% \mathrm{~PB}$. This fact is interesting because of the high availability of PP in the northern region of ES (Brazil) in detriment of $\mathrm{PB}$ and $\mathrm{CF}$.

According to the statistical analysis, only $\mathrm{T} 2$ treatment $(10 \% \mathrm{PP}+30 \% \mathrm{CH}+15 \% \mathrm{CF}+45 \%$ 
PB) was statistically superior to the control ( $\mathrm{P}<$ $0.05)$. The other treatments did not differ statistically from the control $(\mathrm{P}>0.05)$. This result may be associated with the adequate proportion of each of the residues in the composition of the T2 substrate, whose physical and chemical attributes favored the higher growth of the seedlings when compared with the other substrates. One of the main characteristics observed by the farmers of coffee seedlings for the determination of the commercial stage is the PH (BERILLI et al., 2014).

It is noteworthy that plant height is an important parameter for morphological analysis, since nutrient deficient plants have poor development, directly affecting their growth (BERTI et al., 2017). It is believed that the higher vegetative growth of seedlings observed in this substrate can be attributed to the greater availability of some nutrients present in the residues, such as nitrogen and potassium (Table 2). Nitrogen is considered an essential plant mineral, contributing to the synthesis of many organic compounds, such as amino acids, proteins, enzymes, and nucleic acids, where an adequate concentration increases the number and size of leaf cells, with an overall increase in leaf production and attributed biomass yield (CHRYSARGYRIS; PANAYIOTOU; TZORTZAKIS, 2016). Potassium, in turn, is the most important and abundant cation in living plant cells and plays an important role as one of the main nutritional elements, affecting various physiological processes, including photosynthesis and transport/translocation of assimilation products (WANG; WU, 2013).

In this experiment, the lowest $\mathrm{PH}$ was obtained in the control treatment (commercial substrate). Already in the alternative substrates, the PH varied between 19.24 and $21.77 \mathrm{~cm}$, whereas, higher values were recorded in other studies carried out on the production of Conilon coffee seedlings. For instance, Meneghelli et al. (2016) incorporated different levels of coffee moinha (coffee drying residue) into the substrate composition of Conilon coffee seedlings in plastic bags at 125 days after planting and obtained $\mathrm{PH}$ results varying from 14.37 to $16.57 \mathrm{~cm}$. Berilli et al. (2014) assessed different proportions of dehydrated tanning sludge as a substrate in the production of Conilon coffee seedlings in a bag at 120 days, reporting $\mathrm{PH}$ data from 0 to $8 \mathrm{~cm}$. Vallone et al. (2010b) investigated different containers and substrates, including the alternative substrate $(65 \%$ carbonized rice husk + $35 \%$ commercial substrate), commercial substrate Plantmax Hortaliças HT ${ }^{\circledR}$ and $70 \%$ soil $+30 \%$ sifted cattle manure, in the production of Arabica coffee seedlings, obtaining $\mathrm{PH}$ results ranging from 14.67 to $16.27 \mathrm{~cm}$ at 120 days.

The NL values obtained in Conilon coffee seedlings grown on alternative substrates (between 9.17 and 10.17) can be considered satisfactory (Table 3) when compared with the results obtained by Berilli et al. (2014). In that study, the use of dehydrated tanning sludge as a substrate in the production of clonal Conilon coffee seedlings did not obtain an NL $>9$, for the plants produced in polyethylene bags at 120 days after planting.

Similarly to the variable NL, the DS values for the Conilon coffee seedlings grown on alternative substrates (4.28 to $4.48 \mathrm{~mm}$ ) can be considered satisfactory (Table 3) when compared with other studies. When studying several types of basal sections and substrates in the growing of clonal seedlings of Conilon coffee, Aquino et al. (2017) did not obtain DS values above $3.6 \mathrm{~mm}$. It must be considered that the authors evaluated the seedlings at 100 days after planting, less time than that in this study (120 days). These results were lower than those found in the current study, using the alternative substrates. Likewise, Dardengo et al. (2013) did not record a DS greater than $3 \mathrm{~mm}$ in Conilon coffee seedlings grown in tubes at 160 days after planting.

The SDM is related to the quality and quantity of leaves (ATAÍDE et al., 2010). This characteristic is important because the leaves constitute one of the main sources of photoassimilates and nutrients for seedling adaptation (MENEGELLI et al., 2018). The mean values of SDM (3.04 to $3.12 \mathrm{~g}$ ) and RDM (1.32 to $1.40 \mathrm{~g}$ ) (Table 3) for Conilon coffee seedlings grown on the alternative substrates were higher than those obtained by Vallone et al. (2010b) and Dardengo et al. (2013). Vallone et al. (2010b) reported averages varying from 0.844 to $0.999 \mathrm{~g}$ for the SDM and 0.223 to $0.250 \mathrm{~g}$ for the RDM when evaluating different recipients and substrates (alternative and commercial) in the production of Arabica coffee seedlings at 150 days. Dardengo et al. (2013) did not attain SDM and RDM values higher than 2.0 and $1.5 \mathrm{~g}$, respectively, for Conilon coffee seedlings grown in tubes with the standard substrate at 160 days after planting.

According to Dutra et al. (2012), the Bioplant ${ }^{\circledR}$ commercial substrate has a high total porosity $(62.57 \%)$ and a high value of maximum water retention capacity $\left(23.55 \mathrm{~mL} / 55 \mathrm{~cm}^{-3}\right)$, which allows excellent water movement and air in their structures, in addition to providing gas exchanges necessary for the proper development of the plant and guaranteeing differentiation and root growth. 
Probably, the alternative substrates used for the production of coffee seedlings in the current study have physical characteristics similar to the commercial substrate Bioplant ${ }^{\circledR}$ since there was no significant difference between the treatments containing the alternative substrates and commercial substrate for the variables NL, DS, SDM and RDM.

In this sense, any of the substrates containing different proportions of the agricultural residues studied $(\mathrm{PP}, \mathrm{PB}, \mathrm{CF}$ and $\mathrm{CH}$ ) may be an alternative to the commercial substrate in the production of Conilon coffee seedlings since most of the growth variables evaluated did not differ from the control (commercial substrate). Among the alternative substrates, the substrate containing $40 \%$
$\mathrm{PP}+30 \% \mathrm{CH}+30 \% \mathrm{~PB}$ can be a great option, due to the high availability of PP in the northern region of ES (Brazil) in detriment of PB and CF. In addition to the economic benefit in the acquisition of the substrate, the production chain becomes environmentally sustainable, taking advantage of the wastes generated in the region and harmonically disposing them into the environment.

\section{ACKNOWLEDGEMENT}

To Federal Institute of the Espírito Santo and Prodif financial support in the revision of this article.

RESUMO: Pesquisas relacionadas ao uso de resíduos agrícolas como alternativas aos substratos comerciais são fundamental para reduzir os custos de produção das mudas de café. O objetivo do trabalho foi avaliar o efeito dos resíduos pó de pimenta (Piper nigrum), casca de café (Coffea), fibra de coco (Cocos nucifera) e casca de pinus (Pinus) como substratos alternativos no desenvolvimento de mudas de café Conilon (Coffea canephora) em tubetes. O experimento foi realizado no viveiro de produção de mudas Demuner, localizado no município de São Roque do Canaã, ES. Foi adotado o delineamento experimental inteiramente casualizado, com seis tratamentos, sendo, T0: Substrato comercial Bioplant ${ }^{\circledR}$ (testemunha); e de T1 ao T5, proporções crescentes de pó-de-pimenta e decrescentes de fibra de coco e casca de pinus (0/20/50; 10/15/45; $20 / 20 ; 20 / 10 / 40,30 / 5 / 35$ e 40/0/30) e proporções fixas de casca de café (30\%). Aos 120 dias após estaqueamento avaliaram-se: altura de planta, número de folhas, diâmetro do coleto, massa de matéria seca da parte aérea e massa de matéria seca radicular. Qualquer um dos substratos contendo diferentes proporções de resíduos agrícolas pode ser uma alternativa ao substrato comercial na produção de mudas de café Conilon, já que a maioria das variáveis de crescimento avaliadas não diferiu da testemunha. Em razão da maior disponibilidade de pó-de-pimenta na região, recomenda-se o substrato contento $40 \%$ de pó-de-pimenta, $30 \%$ de casca de café e $30 \%$ de casca de pinus.

PALAVRAS-CHAVE: Coffea canephora. Resíduos agrícolas. Crescimento.

\section{REFERENCES}

ALMEIDA, S. L. S.; COGO, F. D.; GONÇALVES, B. O.; RIBEIRO, B. T.; CAMPOS, K. A.; MORAIS, A. R. Adição de resíduos orgânicos ao substrato para produção de mudas de café em tubete. Revista Agroambiental, Pouso Alegre, v. 3, n. 2, p. 9-13, ago. 2011. https://doi.org/10.18406/2316-1817v3n22011326

AQUINO, L. P.; SCHMIDT, R.; DUBBERSTEIN, D.; DIAS, J. R. M. Cortes basais e substratos na formação de mudas clonais de cafeeiro canéfora. Coffee Science, Lavras, v. 12, n. 1, p. 9-16, jan./mar. 2017. https://doi.org/10.25186/cs.v12i1.1182

ASSIS, A. M.; UNEMOTO, L. K.; YAMAMOTO, L. Y.; LONE, A. B.; SOUZA, G. R. B.; FARIA, R. T.; ROBERTO, S. R.; TAKAHASHI, L. S. A. Cultivo de orquídea em substratos à base de casca de café. Bragantia, Campinas, v. 70, n. 3, p. 544-549, 2011. https://doi.org/10.1590/S0006-87052011000300009

ATAÍDE, G. DA MATA; CASTRO, R. V. C.; SANTANA, R. C.; DIAS, B. A. S.; CORREIA, A. C. G.; MENDES, A. F. N. Efeito da densidade na bandeja sobre o crescimento de mudas de eucalipto. Revista Trópica: Ciências Agrárias e Biológicas, Chapadinha, v. 4, n. 2, p. 21-26, 2010. 
BERILLI, S. DA SILVA; QUIUQUI, J. P. C.; REMBINSKI, J.; SALLA, P. H. H.; BERILLI, A. P. C. G.; LOUZADA, J. M. Utilização de lodo de curtume como substrato alternativo para produção de mudas de café Conilon. Coffee Science, Lavras, v. 9, n. 4, p. 472-479, out./dez. 2014.

BERTI, C. L. F.; KAMADA, T.; DA SILVA, M. P.; MENEZES, J. F. S.; OLIVEIRA, A. C. S. Crescimento de mudas de baru em substrato enriquecido com nitrogênio, fósforo e potássio. Cultura Agronômica, Ilha Solteira, v. 26, n. 2, p. 191-202, 2017.

BRAUN, H.; ZONTA, J. H.; LIMA, J. S. DE SOUZA; DOS REIS, E. F.; DA SILVA, D. P. Desenvolvimento inicial do café Conilon (Coffea canephora Pierre) em solos de diferentes texturas com mudas produzidas em diferentes substratos. Idesia, Chile, v. 27, n. 3, p. 35-40, set./dez. 2009. https://doi.org/10.4067/S071834292009000300006

CHRYSARGYRIS, A.; PANAYIOTOU, C.; TZORTZAKIS, N. Nitrogen and phosphorus levels affected plant growth, essential oil composition and antioxidant status of lavender plant (Lavandula angustifolia Mill.). Industrial Crops and Products, v. 83, p. 577-586, 2016. DOI: 10.1016/j.indcrop.2015.12.067.

DARDENGO, M. C. J. D.; DE SOUSA, E. F.; DOS REIS, E. F.; DE AMARAL GRAVINA, G. Crescimento e qualidade de mudas de café Conilon produzidas em diferentes recipientes e níveis de sombreamento. Coffee Science, Lavras, v. 8, n. 4, p. 500-509, out./dez. 2013. DOI: 10.25186/cs.v8i4.512.

DE MATOS A. T. Manual de análise de resíduos sólidos e águas residuárias. Viçosa: UFV, 2015. 149 p.

DUTRA, T. R.; MASSAD, M. D.; SARMENTO, M. F. Q.; DE OLIVEIRA, J. C. Emergência e crescimento inicial da canafístula em diferentes substratos e métodos de superação de dormência. Revista Caatinga, Mossoró, v. 25, n. 2, p. 65-71, mar./jun. 2012.

MARTIN, T. N; DE LIMA, L. B.; RODRIGUES, A.; GIRARDI, E.; FABRI, E. G.; MINAMI, K. Utilização de vermiculita, casca de pinus e carvão na produção de mudas de pepino e de pimentão. Acta Scientiarum Agronomy, Maringá, v. 28, n. 1, p. 107-113, jan./mar. 2006. https://doi.org/10.4025/actasciagron.v28i1.1687

MARTINS, L. D.; MACHADO, L. S.; TOMAZ, L. A.; AMARAL, J. F. T. The nutritional efficiency of Coffea spp. A review. African Journal of Biotechnology, v. 14, n. 9, p. 728-734, 2015.

https://doi.org/10.5897/AJB2014.14254

MENEGHELli, C. M.; LO MONACO, P. A. V.; HADDADE, I. R.; MENEGHELLI, L. A. M.; KRAUSE, M. R. Resíduo da secagem dos grãos de café como substrato alternativo em mudas de café Conilon. Coffee Science, Lavras, v. 11, n. 3, p. 330-335, jul./set. 2016.

MENEGHELLI, L. A. M.; LO MONACO, P. A. V.; KRAUSE, M. R.; GUISOLFI, L. P.; ALMEIDA, K. M.; VALLE, J. M.; VIEIRA, G. H. S. Utilization of agricultural residues as alternative substrates in the production of Conilon coffee seedlings. Journal of Experimental Agriculture International, v. 21, n. 4, p. 1-6, 2018. https://doi.org/10.9734/JEAI/2018/39797

OLIVEIRA, I. P.; OLIVEIRA, L. C.; MOURA, C. S. F. T. Cultivo do café: fases do desenvolvimento e algumas técnicas de manejo. Revista Faculdade Montes Belos, São Luís de Montes Belos, v. 5, n. 4, p. 33-55, 2012.

SAN-TANA DE ALMEIDA, S. L.; COGO, F. D.; GONÇALVES, B. O.; RIBEIRO, B. T.; CAMPOS, K. A.; DE MORAIS, A. R. Adição de resíduos orgânicos ao substrato para produção de mudas de café em tubete. Revista Agrogeoambiental, Pouso Alegre, v. 3, p. 2, p.9-13, 2011. https://doi.org/10.18406/2316$1817 \mathrm{v} 3 \mathrm{n} 22011326$ 
SILVA, F. DE ASSIS SANTOS; DE AZEVEDO, C. A. V. The Assistat software version 7.7 and its use in the analysis of experimental data. African Journal of Agricultural Research, v. 11, n. 39, p. 3733-3740, set. 2016. https://doi.org/10.5897/AJAR2016.11522

TOMAZ, M. A. et al. Produção de mudas e plantio. In: SAKIYAMA N. S.; MARTINEZ, H.; TOMAZ, M.; BORÉM, A. Café arábica: do plantio à colheita. Viçosa, Editora UFV, 2015. p.46-63.

VALlONE, H. S.; GUIMARÃES, R. J.; MENDES, A. N. G.; DA CUNHA, R. L.; CARVALHO, G. R.; DIAS, F. P. Efeito de recipientes e substratos utilizados na produção de mudas de cafeeiro no desenvolvimento inicial em casa de vegetação, sob estresse hídrico. Ciência e Agrotecnologia, Lavras, v. 34, n. 2, p. 320-328, mar./abr. 2010a. https://doi.org/10.1590/S1413-70542010000200008

VALlONE, H. S.; GUIMARÃES, R. J.; MENDES, A. N. G.; SOUZA, C. A. S.; DA CUNHA, R. L.; DIAS, F. P. Diferentes recipientes e substratos na produção de mudas de cafeeiros. Ciência e Agrotecnologia, Lavras, v. 34, n. 1, p. 55-60, jan./fev. 2010b. https://doi.org/10.1590/S1413-70542010000100006

ZORZETO, T. Q.; DECHEN, S. C. F.; DE ABREU, M. F.; JÚNIOR, F. F. Caracterização física de substratos para plantas. Bragantia, Campinas, v. 73, n. 3, p. 300-311, 2014. https://doi.org/10.1590/1678-4499.0086

WANG, Y.; WU, W. H. Potassium transport and signaling in higher plants. Annual review of plant biology, v. 64, p. 451-476, 2013. https://doi.org/10.1146/annurev-arplant-050312-120153 